\title{
IMPROVEMENT OF THE LOGISTIC PROCESSES USING THE REVERSE LOGISTICS CONCEPT
}

Zbigniew Lukasik ${ }^{1}$ Aldona Kuśmińska-Fijalkowska, ${ }^{1, *}$, Sylwia Olszańska²

${ }^{1}$ Faculty of Transport, Electrical Engineering and Computer Science, Kazimierz Pulaski University of Technology and Humanities in Radom, Radom, Poland

${ }^{2}$ Chair of Logistics and Process Engineering, University of Information Technology and Management based in Rzeszow, Rzeszow, Poland

*E-mail of corresponding author: a.kusminska@uthrad.pl

\section{Resume}

Reverse logistics differs significantly from such fields as management of waste, of which the goal is, above all, efficient and effective collection and processing of waste. Therefore, it can be said that reverse logistics refers to such streams of flows in which it is possible to recover the value from discontinued products and situation, in which solution is contribution to a new supply chain. Therefore, in this aspect, the fundamental pillar is transport, in which the crucial element is management of transport process, above all, planning of changes improving this process to better control the degree of their execution.

In this article, the authors examined transport process in a real object in the context of improvement. As a result, practical aspects of planning and control of organization of transport were presented.

Available online: https://doi.org/10.26552/com.C.2021.3.A174-A183

\section{Article info}

Received 9 September 2020

Accepted 4 October 2020

Online 19 May 2021

\section{Keywords:}

reverse logistics, system approach, logistics process

ISSN 1335-4205 (print version) ISSN 2585-7878 (online version)

\section{Introduction}

Transport is an inherent element of waste management system. Therefore, an integrated look at the concepts of management of the waste flows is important. As a result, increased interest in waste management is an effect of various interconnected actions [1-3]. Above all, it should be emphasized that all the tasks, connected with the waste management, fall within competences of logisticians [4-6]. In this aspect, a person managing transport must perceive organization of transport from the angle of execution of quantified partial tasks to achieve effective planning and execution of transport process [7-13]. A permanent goal in a transport enterprise is improvement of processes and as a result, implementation of effective methods of management to gain competitive advantage [14-17]. Therefore, the most advantageous is management of the transport process organization, as intentionally interconnected sequences of actions, transforming input state into output state, executing the plan of delivery of goods to clients in Just-in-Time and Door-to-Door system [18-21].

\section{The subject, goal and the most important} tasks of the reverse logistics

The reverse logistics is attractive showing both area of research and differences in determination of the scope of its application. There is also high compliance to the subject and tasks of the reverse logistics. The subject of reverse logistics is flow of waste and information connected with this flow. These flows should be configured in such a way to minimize harmful impact of waste on natural environment in the most functional and consistent way. To achieve it, one needs organizational, technical and financial coordination of the processes' course and logistic actions. The goal of reverse logistics is to combine the mentioned flows in time and space and by optimizing the costs of flows, guarantee proper condition of natural environment.

The scope of tasks of reverse logistics, resulting from the concept of the Reverse Logistics Association (RLA), is very significant in the aspect of the processes execution. Table 1 presents a list with the tasks of traditional logistics. 
Table 1 Logistics and reverse logistics in accordance with concept of RLA

supply chain - after - sales supply chain

product life cycle

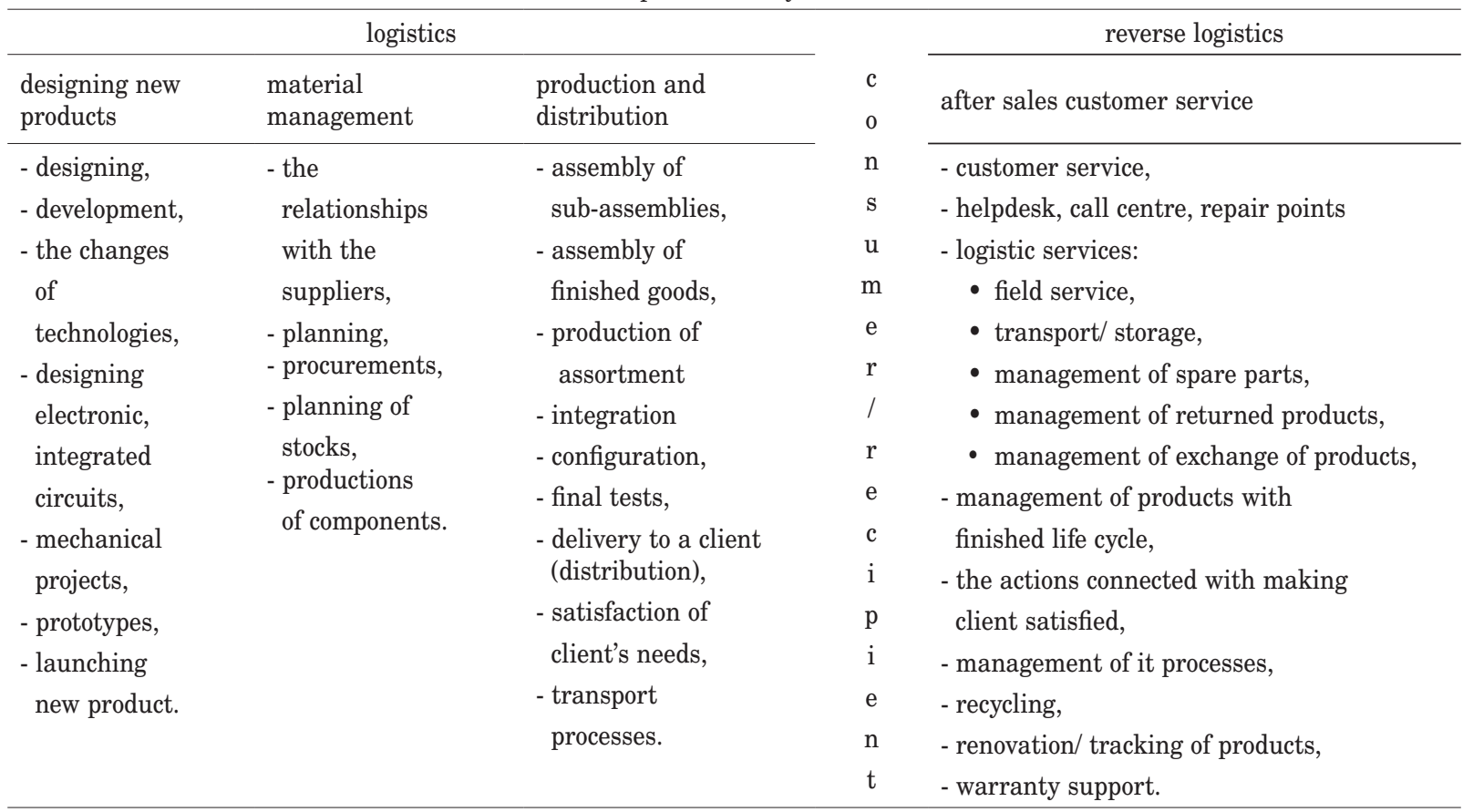

\section{System approach in waste management}

System approach is the key to understand logistics. This issue occurs on the spatial, organizational and information plane. Therefore, this approach requires comprehensive thinking due to connections and relations. This ideology is based on an assumption that all the actions in a specific enterprise that are involved in physical flow and storage of raw materials, semi-finished products, as well as finished goods, should be treated not as individual parts, but as a whole. As a result, application of the system approach in logistics helps to eliminate sub-optimization of solutions since the single elements of the system aim at such cooperation that is required in all the parts of comprehensively assessed logistic system [22].

It can also be said that a system is a set of interconnected components allowing to achieve established goal. In addition, while defining a logistic system, one should present a position of D. M. Lambert who considered the system starting from input elements, then their transformation and ending with output elements. The input elements include stocks, logistic material base and information, whereas the output element is a result of actions of the system with reference to products or services according to logistic orientation effective for the clients. The logistic system must be built in "the best way” (optimo modo) because the goal of its building is to guarantee the execution of logistic processes [23]. Above all, around this system, the connections between the elements of infrastructure have the character of flow of goods, people and information. In order to achieve the coordinated development, one should not only implement and improve effective methods of management, but one should take all the potential environmental factors affecting the human environment into account. Such factors include logistic functioning of integrated waste management system. In this aspect, integration means combination of particular elements of the system with use of tasks of modern logistics.

\section{The application of reverse logistics within the scope of waste disposal and their reuse}

A significant task of reverse logistics concerning waste disposal is planning the routes of the vehicles. The routes should be planned in an optimal way to provide efficient service for the towns/cities with the lowest possible costs of the waste collection, meeting also the requirements of transport congestion, frequency of service of stockpiles and minimization of negative impact on environment.

Two systems of waste collection were distinguished: 1) single-stage system - in this case, transport directly to a place of neutralization,

2) two-stage system - transport is provided with the of transhipment stations in which the waste is collected temporarily.

It is widely believed that the two-stage transport is much better than single-stage transport because it allows to increase economic efficiency and improve the efficiency and operating efficiency of the vehicles for waste collection. In addition, the two-stage transport is more profitable since the expenditure, incurred on the vehicles and transhipment station, quickly pay for itself. 


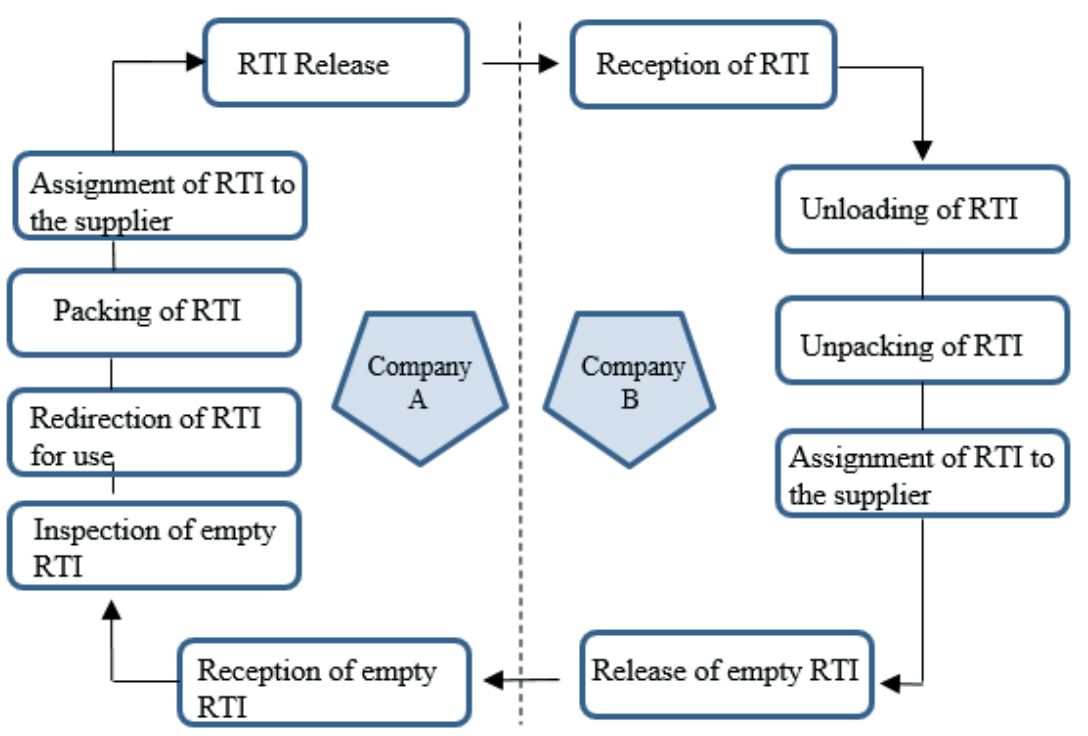

Figure 1 The process of release and reception of returnable transport items

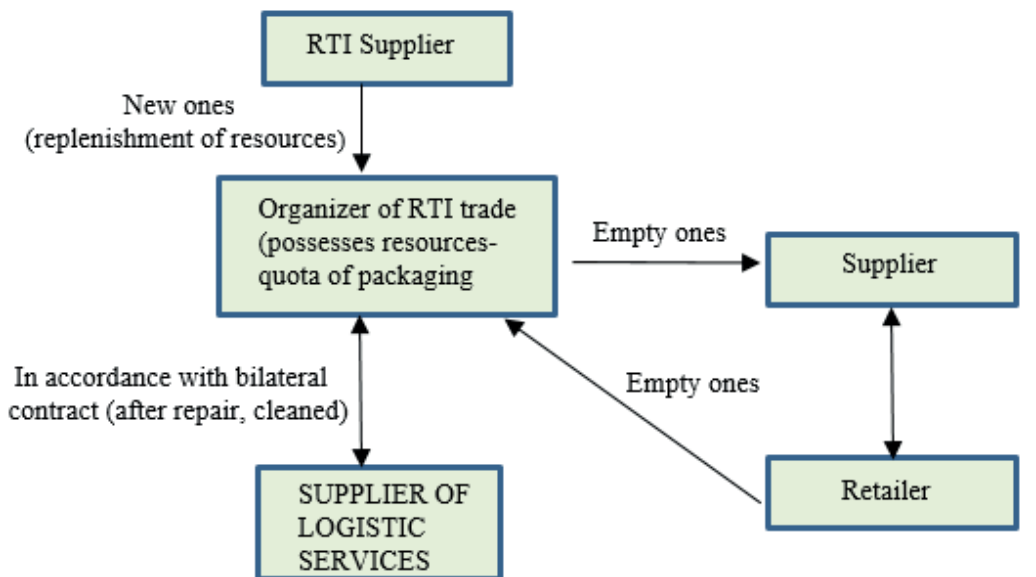

Figure 2 Physical flows in the RTI system - Returnable Transport Items

The types of selection of the transport means used in the waste management depend, above all, on a system of the waste collection, type of containers that are used and on whether waste for recycling is collected at the same time and in the same vehicle. The goals of organization and technique of the waste disposal should be:

- increasing multifunctionality of the fleet,

- constant improvement of the fleet,

- modernizing mechanization of the waste loading and as a result, reduction of the transport teams number,

- increasing the work comfort of the drivers.

To sum up, it may be concluded that execution of tasks of the reverse logistics within the waste disposal from the places of storage has significant impact on efficient functioning of the waste management logistic system.

Specific sections of path of life of the packaging are harmonized with subsequent processes. Above all, effective management of returnable transport items (RTI) is becoming increasingly important in modern supply chains (Figure 1) [24-25].

In the processes that include the rules of efficient management of returnable transport items, three basic entities are distinguished:

1. RTI producers,

2. suppliers,

3. customers

Moreover, in some supply chains there are other entities, for example, logistic operator who is responsible for sending materials or for reception of returnable transport items from the customers [26].

In such a system of exploitation, an inherent element are the following problems, among others:

- lack of accurate control of the state of the packaging - the consequence is increased stocks,

- $\quad$ expensive production and return of the packaging - resulting in additional costs and risk of errors, slowing down the process,

- the processes of control of returnable transport items take much time that would be used in a different, much more profitable way. 


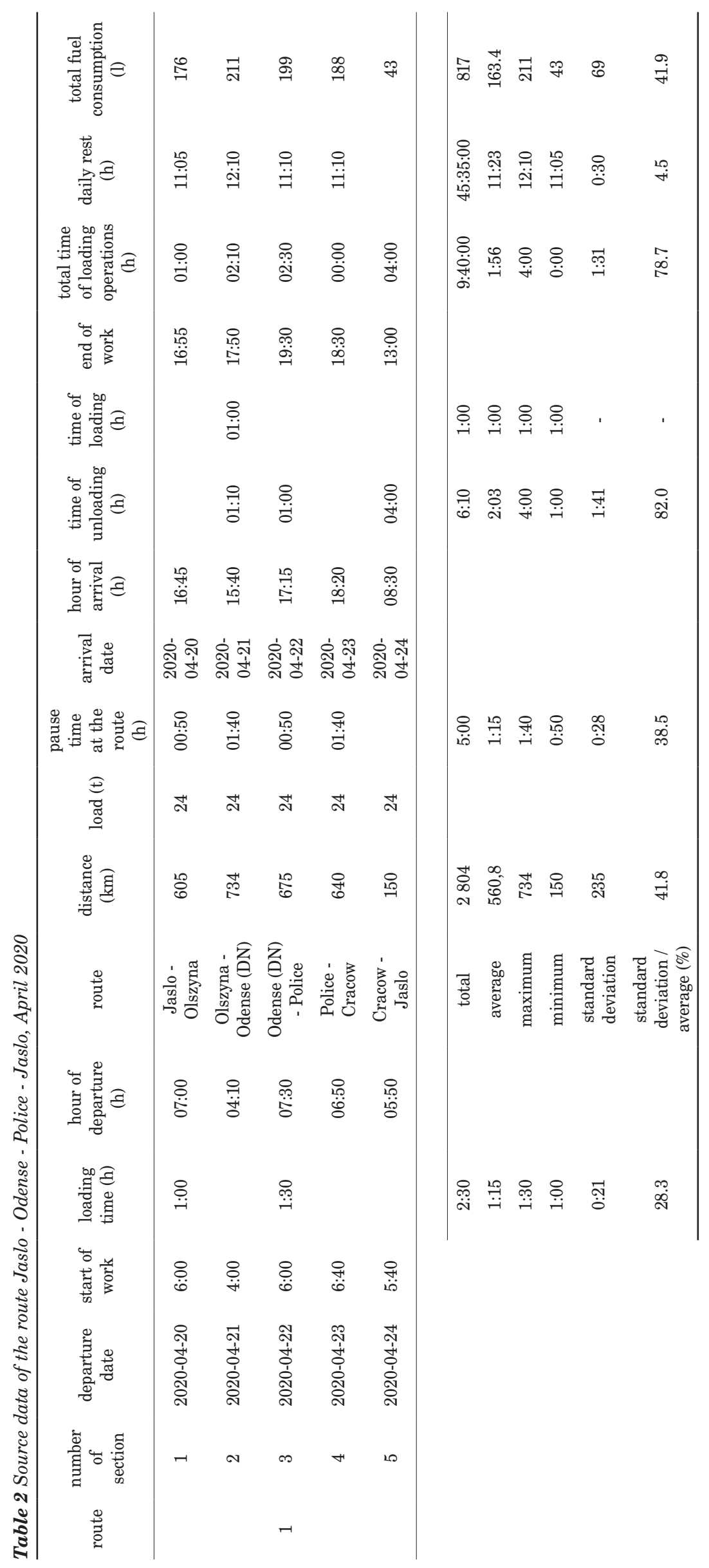




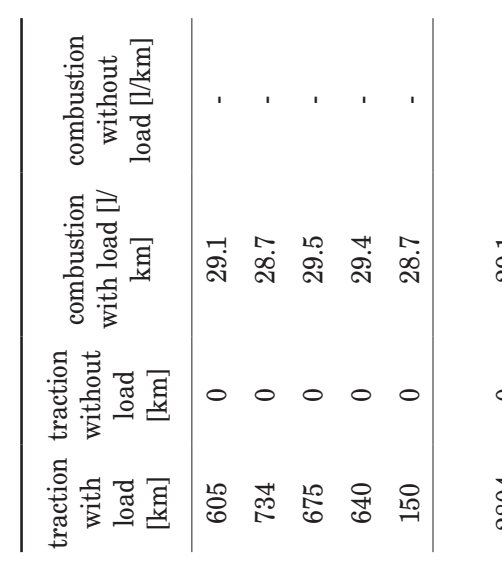

ลำ

$\circ \stackrel{0}{\circ}$

ث্ণ

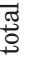

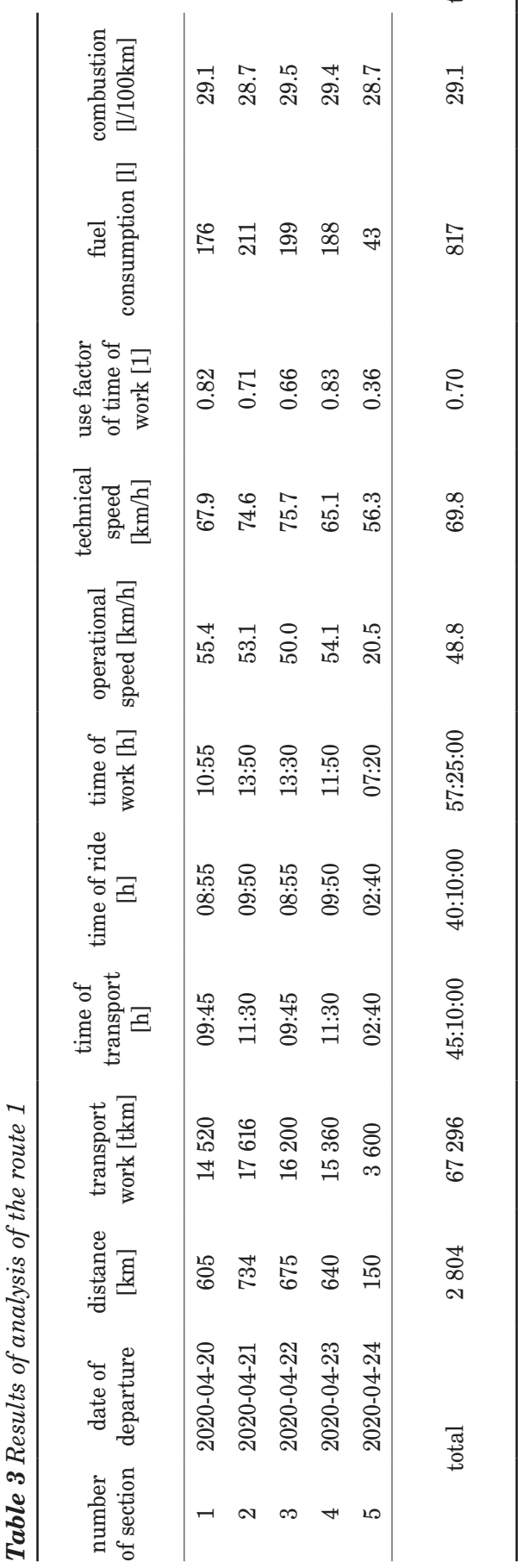

Therefore, the function of logistics in this aspect is limiting such problems. Therefore, the logistic management in this case was presented on Figure 2.

\section{An analysis of transport process executed in the examined transport enterprise}

The subject of analysis is a transport enterprise and transport processes executed in it. Examined enterprise provides transport services only by the road transport. The enterprise has decided to build competitive strategy to strengthen its position. Therefore, to single out their offer on the market, the managers have decided to extend transport potential for provision of services of transport of waste using specialized fleet. The managers also want to become a leader on the market of enterprises dealing with transport of waste. Therefore, the authors analysed executed transport processes in the aspect of efficiency. As a result, statistical analysis was conducted showing that time can be saved during the executed transport process.

Examined enterprise executes transport tasks both in a single-stage and two-stage system, however, most of the orders from the clients include execution of transport in a single-stage system. Because the superior attributes in organization of transport process include quality, time and costs, it is important for initial execution of a process, that is, from the moment of reception of a transport order to its final execution, to be coordinated and without delays. As a result, these actions lead to meeting the objectives of examined transport enterprise, because the minimization of costs and maximum profit are the most important for this enterprise.

The subject of analysis is route 1, executed in April 2020, where the return cargo is loaded in Police. This route consists of transport of three cargos:

- the first one on the route between Jaslo and Odense in Denmark,

- the second one on the route between Odense and Police,

- and the third one on the route between Police and Jaslo.

The source data are presented in a five-segment system and contain such information as: number of route, vehicle make, date, hour and place of departure, distance of drive, weight of cargo, date, hour and place of arrival, time of pauses on the route, time of loading operations, time of daily rest (Table 2).

Based on the source data, values of sums, average, maximal and minimum values, their standard deviation, if it was possible, were calculated and the value of standard deviation was compared with the average value in percentage terms. Directly from the monthly data, sums of distances, times of loading, unloading, pauses, daily rests, fuel consumption were calculated. Apart from the monthly sums, the average values of these parameters were calculated, their maximal and 


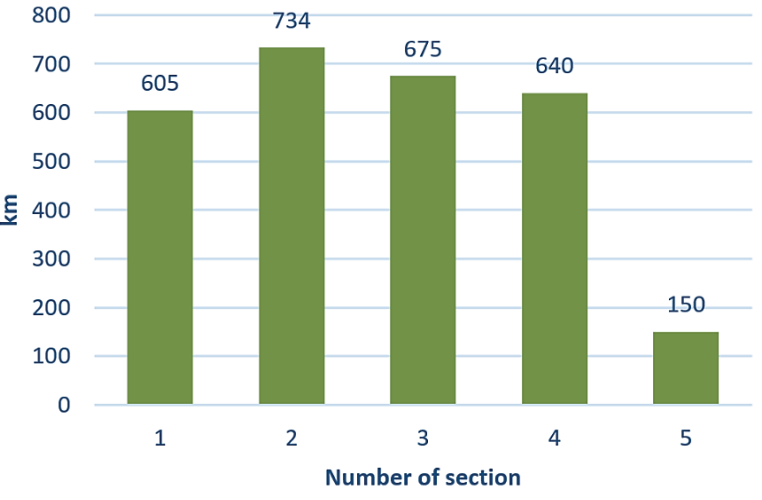

Figure 3 Daily distances

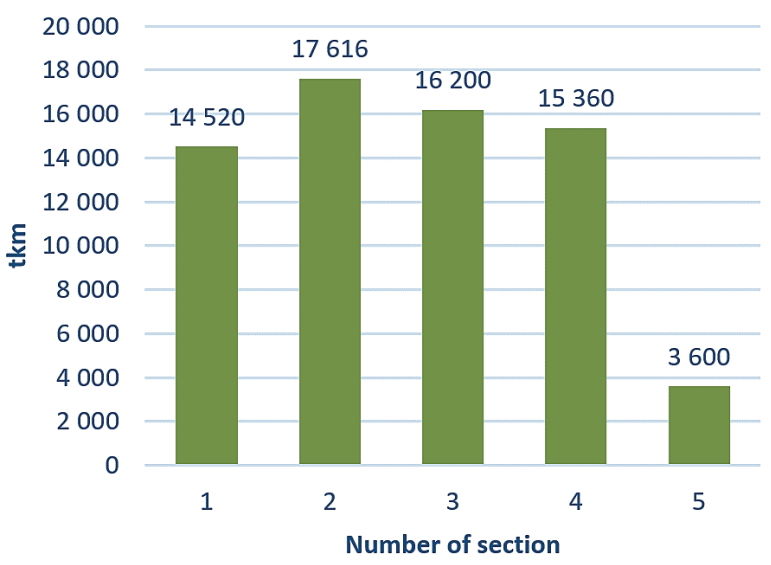

Figure 4 Daily transport work

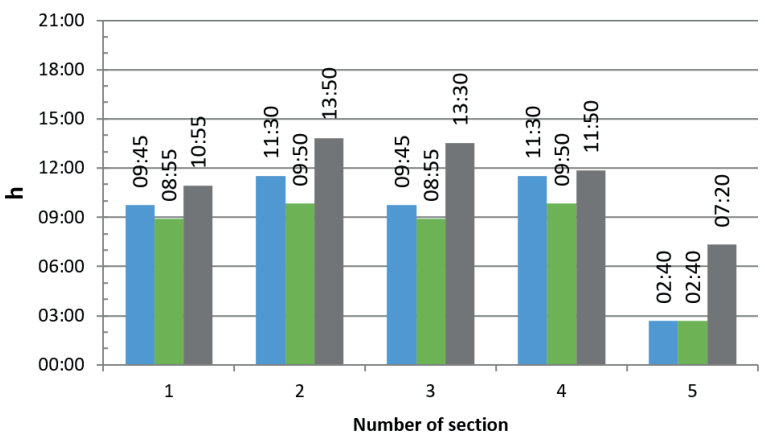

Time of transport $\quad$ Time of ride $\square$ Time of work

Figure 5 Daily time of transport, ride and work

minimum values, standard deviation were determined and compared to average value. An analysis was conducted by calculating such rates as: transport work, time of transport, time of ride, time of work, operating speed, technical speed, fuel consumption (Table 3).

Results of analysis of the route 1 , that is, daily distances, daily transport work, daily time of transport, ride and work, as well as daily fuel consumption, daily combustion and technical speed were presented in Figures 3 to 8 .

Figure 3 shows daily distances of the route in $\mathrm{km}$ as a function of a section number. Diverse distances of the routes in subsequent days were observed. During

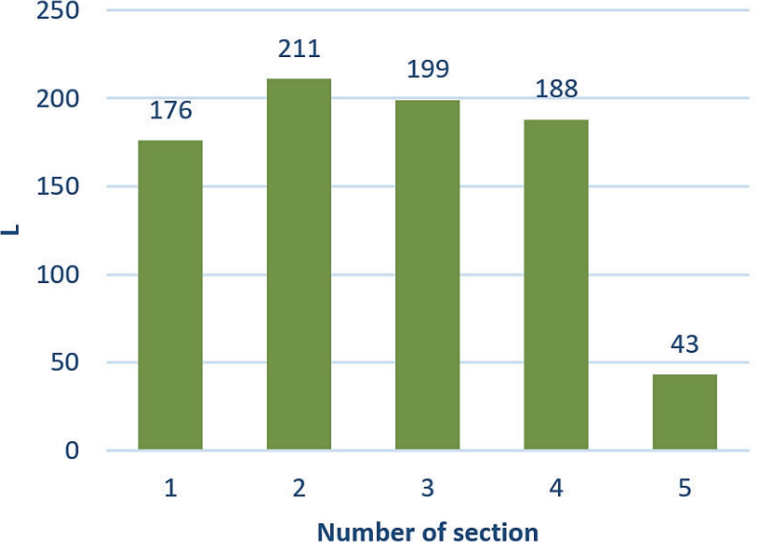

Figure 6 Daily fuel consumption

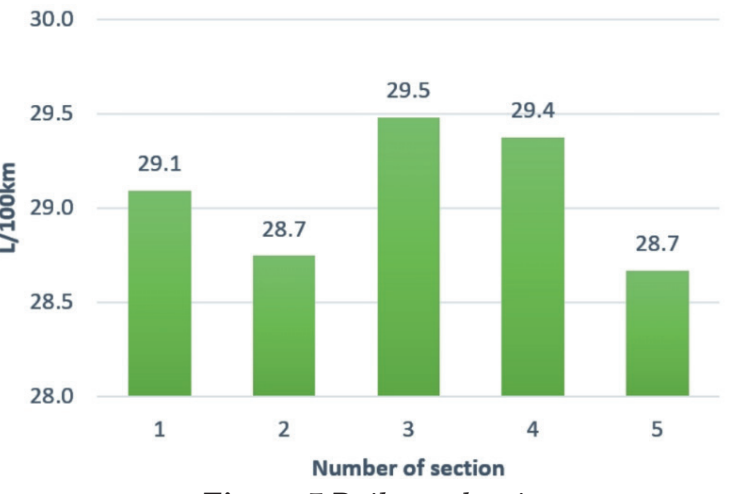

Figure 7 Daily combustion

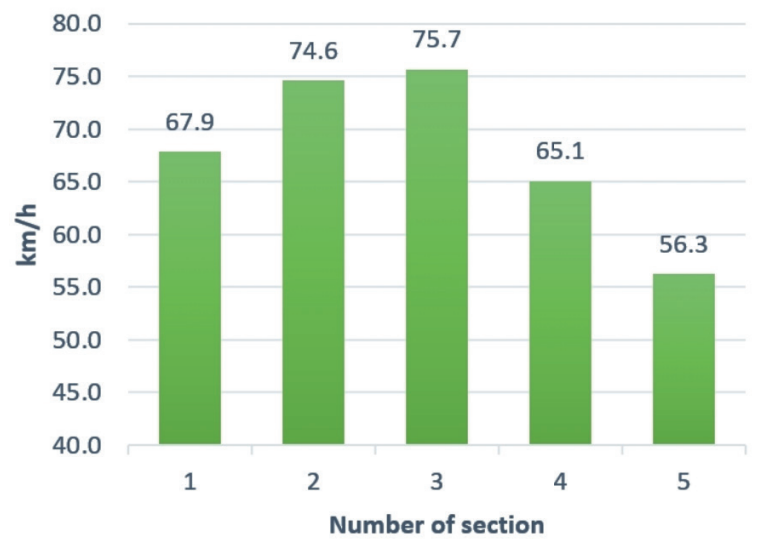

Figure 8 Technical speed

the days $1,2,3,4$, these distances are between 605 and $734 \mathrm{~km}$, therefore, they are similar to a maximum daily range. Therefore, in these sections, there is a risk of inability to reach a point of destination in the event of even minor disruptions of traffic flow. Whereas, on a day 5 , daily length of the route is much shorter, $150 \mathrm{~km}$, which results from the way of organization of the route.

Conducted analysis showed that daily transport work is diverse analogous to diversity of daily mileage (Figure 4).

Daily duration of transport is almost identical in all the sections of transport, because during the days: 1,3 , it is $9 \mathrm{~h} 45 \mathrm{~min}$, whereas, in the sections 2 , 4 , it is $11 \mathrm{~h} 30$ 


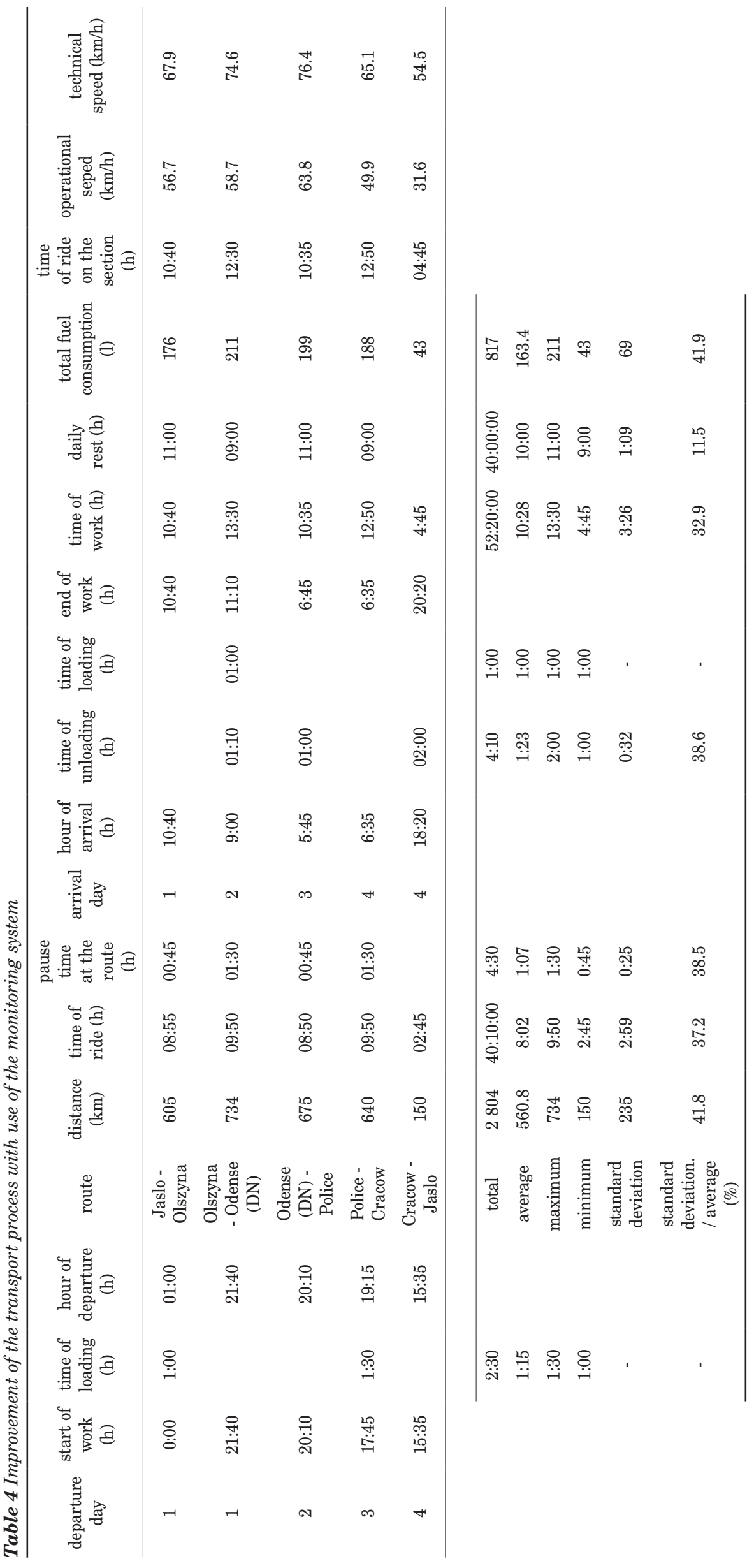


min, only in section 5 , it is $2 \mathrm{~h} 40$ min. Daily duration of drive is analogous to duration of transport. In the event of daily working time, there is high diversity in every section of the route (Figure 5).

Daily fuel consumption is diverse similarly to daily distances. However, in specific sections, small differences in fuel consumption can be observed, which can be caused by variability of the road conditions (Figure 6).

An analysis conducted by the authors showed that in section 3 , there is the highest daily burning 29.5 $\mathrm{L} / 100 \mathrm{~km}$, whereas the lowest $28.7 \mathrm{~L} / 100 \mathrm{~km}$ was found in section 5 (Figure 7).

The highest technical speed was recorded in section 3 , which was $75.7 \mathrm{~km} / \mathrm{h}$ and the lowest $56.3 \mathrm{~km} / \mathrm{h}$ was in section 5 (Figure 8).

As a result of research conducted in a real object, the authors perceived the opportunity of improving the transport process by implementing innovative solutions.

\section{Improvement of the transport process executed with use of an innovative monitoring system}

Time of drive of analysed route $\mathbf{1}$ is 40 hours and 10 minutes and it is divided into five working days. It should be checked whether application of the monitoring system should have impact on shortening the time of transport. In order to check the examined route 1 , Table 4 was created. To simplify it, it was assumed that departure starts at 0:00 o'clock, but table allows to change the moment of departure. The set of data was also changed - time of loading and unloading, time of ride, pauses. Data are entered to the field of grey background, whereas, remaining data such as hours of departure, arrival, end of a working shift, time of work and day are not changed.

Shortening the time of execution of this transport to 4 days, while maintaining 5 working shifts is possible in the event of maintaining the standard worktime and driver's rest (Table 4). To sum up, in the route 1 , time of drive can be shortened by 1 day. It generates savings because vehicle and driver can be used for an additional transport order.

Conducted analysis showed that the selected route is optimal. Alternative routes are longer, the roads are of the lower categories and require longer time of drive. Only in the run to Odense, change of route can be considered, that is, ride „there” through Police, which would shorten the time of drive through Germany and reduce the amount of remuneration of a driver because the number of hours paid according to German minimum rates would be lower. What is more, in the route 1 , a place of a daily rest on the way back from Cracow can be changed to a town situated about $100 \mathrm{~km}$ closer. It would enable to avoid the ten-hour shift on the route between Police and Cracow, reducing it to about 8 hours and 30 minutes, whereas this distance can be covered on the next short shift to Jaslo. The prolonged unloading in Jaslo, lasting 4 hours is inexplicable. Obtained data showed that operation of unloading lasts on average about 2 hours, therefore, one can assume that there was some problems, for example, waiting for unloading.

\section{Conclusions}

A domain of reverse logistics is, above all, the processes in an integrated waste management system, of which inherent element is transport. Moreover, the use of logistics in the concept of the waste management processes gives many benefits, including unification of the processes of the waste streams flows and also, related to the flows, the correlated flow of information, which, as a result, allows to reduce the costs of service of the processes through effective use of resources.

The essence in a transport enterprise is provision of the high standard services, therefore, the managers often face the pressure of necessity of adjustment of the services to growing client-oriented market needs. Therefore, the forwarding agent should maximize the efficiency of executed transport process, which was shown in this article to maintain the high competitiveness level.

The authors of this article conducted research on transport process in a real object, which is one of the most important links of the supply chain in reverse logistics. As a result, they showed an improvement within the conducted transport process in reverse logistics. Therefore, due to the fact of multidimensionality of this problem, practical directions of actions adopted in the article aiming at improvement of planning and conducting of transport may be used by the forwarders in making decisions related to management of logistic processes. Furthermore, presented modern concept of management is becoming a driving force in rationalization of the actions in terms of flow of goods and information, as well as improvement of adopted strategy of conducting the transport processes directed towards, above all, duration, quality, flexibility and innovativeness.

\section{References}

[1] JANCZEWSKI, J. Automotive reverse logistics networks. Selected exemples (in Polish). Zeszyty Naukowe Wyzszej Szkoly Humanitas. Zarzadzanie [online]. 2016, 2, p. 231-251. ISSN 1899-8658. Available from: https://doi.org/10.5604/18998658.1210118 
[2] LIN, C., CHOY, K. L., HO, G. T. S., CHUNG, S. H., LAM, H. Y. Survey of green vehicle routing problem: past and future trends. Expert Systems with Applications: An International Journal [online]. 2014, 41(4), p. 1118-1138. ISSN 0957-4174. Available from: https://doi.org/10.1016/j.eswa.2013.07.107

[3] LI, Y., LU, L. Research on B2C reverse logistics service quality evaluation system. In: 5th International Conference on E-Business and Applications ICEBA 2019: proceedings [online]. 2019. ISBN 978-1-4503-6262-7, p. 10-15. Available from: https://doi.org/10.1145/3317614.3317631

[4] ELMERINI, R., BENSLIMANE, M., ZOUADI, T. Reverse logistic optimization: application to the collect and the reuse of reusable containers. In: International Conference on Learning and Optimization Algorithms: Theory and Applications LOPAL '18: proceedings [online]. 2018. ISBN 978-1-4503-5304-5, p. 1-5, art. no. 62. Available from: https://doi.org/10.1145/3230905.3230966

[5] HAUDER, V. A., BEHAM, A., WAGNER, S., AFFENZELLER, M. Optimization networks for real-world production and logistics problems. In: Genetic and Evolutionary Computation Conference Companion GECCO '17: proceedings [online]. 2017. ISBN 978-1-4503-4939-0, p. 1411-1414. Available from: https://doi.org/10.1145/3067695.3092959

[6] CEMPIREK, V., NACHTIGALL, P., SIROKY, J. Security in Logistics. Open Engineering [online]. 2016, 6(1), p. 637-641. eISSN 2391-5439. Available from: https://doi.org/10.1515/eng-2016-0082

[7] ULLRICH, C. A. Integrated machine scheduling and vehicle routing with time windows. European Journal of Operational Research [online]. 2013, 227, p. 152-165. ISSN 0377-2217. Available from: http://dx.doi.org/10.1016/j. ejor.2012.11.049

[8] CAO, E., LAI, M., YANG, H. Open vehicle routing problem with demand uncertainty and its robust strategies. Expert Systems with Applications [online]. 2014, 41, p. 3569-3575. ISSN 0957-4174. Available from: http://dx.doi. org/10.1016/j.eswa.2013.11.004

[9] CHE, Z. H., CHIANG, T.-A., HSIAO, K. H., CHEN, C. L., CHANG, J. Y. Cross-stage reverse logistics planning via a genetic algorithm. In: International Conference on Algorithms, Computing and Systems ICACS '17: proceedings [online]. 2017. ISBN 978-1-4503-5284-0, p. 98-101. Available from: https://doi.org/10.1145/3127942.3127944

[10] GHANNADPOUR, S. F., NOORI, S, TAVAKKOLI-MOGHADDAM, R., GHOSEIRI, K. A multi-objective dynamic vehicle routing problem with fuzzy time windows: model, solution and application. Applied Soft Computing [online]. 2014, 14, p. 504-527. ISSN 1568-4946. Available from: http://dx.doi.org/10.1016/j.asoc.2013.08.015

[11] PECENY, L., MESKO, P., KAMPF, R., GASPARIK, J. Optimisation in transport and logistic processes. Transportation Research Procedia [online]. 2020, 44, p. 15-22. ISSN 2352-1465. Available from: https://doi. org/10.1016/j.trpro.2020.02.003

[12] OCALIR-AKUNAL, E. V. Decision support systems in transport planning. Procedia Engineering [online]. 2016, 161, p. 1119-1126. ISSN 1877-7058. Available from: https://doi.org/10.1016/j.proeng.2016.08.518

[13] KAMPF, R. Optimization of delivery routes using the little's algorithm. Nase More [online]. 2018, 65(4), p. 237-239. ISSN 0469-6255, eISSN 1848-6320. Available from: https://doi.org/10.17818/NM/2018/4SI.13

[14] CEMPIREK, V., VRBOVA, P., ZAKOROVA, E. The possibility of transferring the transport performance on railway transport. MATEC Web of Conferences [online]. 2017, 134(2), 00006. eISSN 2261-236X. Available from: https://doi.org/10.1051/matecconf/201713400006

[15] FU, J., JENELIUS, E. Transport efficiency of off-peak urban goods deliveries: a Stockholm pilot study. Cases Studies on Transport Policy [online]. 2018, 6(1), p. 156-166. ISSN 2213-624X, eISSN 2213-6258. Available from: https://doi.org/10.1016/j.cstp.2018.01.001

[16] PILLAC, V., GUERET, CH., MEDAGLIA, A. L. An event- driven optimization framework for dynamic vehicle routing. Decision Support System [online]. 2012, 54(1), p. 414-423. ISSN 0167-9236. Available from: https://doi. org/10.1016/j.dss.2012.06.007

[17] SIMANOVA, L., STASIAK-BETLEJEWSKA, R. Monitoring and improvement of logistic processes in enterprises of the Slovak Republic. LOGI - Scientific Journal on Transport and Logistics [online]. 2019, 10(1), p. 62-71. eISSN 2336-3037. Available from: https://doi.org/10.2478/logi-2019-0007

[18] PANDELIS, D. G, KARAMATSOUKIS, C. C., KYRIAKIDIS, E. G. Finite and infinite- horizon single vehicle routing problems with a predefined customer sequence and pickup and delivery. European Journal of Operational Research [online]. 2013, 231(3), p. 577-586. ISSN 0377-2217. Available from: http://dx.doi. org/10.1016/j.ejor.2013.05.050

[19] LEI, H., LAPORTE, G., GUO, B. The vehicle routing problem with stochastic demands and split deliveries. INFOR: Information Systems and Operational Research [online]. 2012, 50(20), p. 59-71. ISSN 0315-5986, eISSN 1916-0615. Available from: https://doi.org/10.3138/infor.50.2.059

[20] AZI, N., GENDREAU, M., POTVIN, J-Y. A dynamic vehicle routing problem with multiple delivery routes. Annals of Operations Research [online]. 2012, 199, p. 103-112. ISSN 0254-5330, eISSN 1572-9338. Available from: https://doi.org/10.1007/s10479-011-0991-3 
[21] CABAN, J., DROZDZIEL, P., KRZYWONOS, L., RYBICKA, I., SARKAN, B., VRABEL, J., Statistical analyses of selected maintenance parameters of vehicle of road transport companies. Advances in Science and Technology Research Journal [online]. 2019, 13(1), p. 1-13. ISSN 2299-8624. Available from: https://doi. org/10.12913/22998624/92106

[22] KOCHANSKI, T. Logistics as a concept of integrated management (in Polish). Warszawa: Akademia Obrony Narodowej, 2003. ISBN 8388062697.

[23] DEMBINSKA-CYRAN, I., JEDLINSKI, M., MILEWSKA, B., Logistics. Selected topics for studying the subject (in Polish). Szczecin: Wydawnictwo Naukowe Uniwersytetu Szczecinskiego, 2001. ISBN 8372411956.

[24] Reusable Transport Items (RTI). Organizational Recommendations. EANCOM-Manual. Koln: Centrale fur Coorganisation $\mathrm{GmbH}, 2003$.

[25] LYSENKO-RYBA, K. The impact of reverse logistics on customers satisfaction. In: Logistics in management sciences. Part II (in Polish). KAUF, S., PISZ, I. (eds.). Lodz - Waszawa: Wydawnictwo SAN, 2017. ISSN 2543-8190, p. 137-146. Available from: http://piz.san.edu.pl/docs/e-XVIII-8-2.pdf

[26] MICHNIEWSKA, K. Recycling logistics in packaging (in Polish). Warszawa: Wydawnictwo Difin, 2013. ISBN 9788376418384. 